\title{
Problematyka obliczania opłat za korzystanie ze środowiska za wydanie uprawnień do emisji gazów cieplarnianych
}

\author{
Wyrok Wojewódzkiego Sądu Administracyjnego w Łodzi z dnia 29 sierpnia \\ 2018 r., II SA/Łd 301/18
}

Wprowadzenie nowych zasad uiszczania opłat za korzystanie ze środowiska za wydane uprawnienia do emisji, określonych w ustawie z dnia 12 czerwca 2015 r. o systemie handlu uprawnieniami do emisji gazów cieplarnianych, wiąże się z liczbą uprawnień do emisji „,wydanych w danym roku na rachunek posiadania operatora". Nie ma możliwości rozliczenia uprawnień przydzielonych podmiotowi korzystającemu ze środowiska na rok 2014 (a wydanych w 2015 r.) według zasad ww. ustawy, ponieważ termin ich rozliczenia już upłynął.

\section{Diana Trzcińska}

Uniwersytet Gdański

diana.trzcinska@ug.edu.pl

ORCID: 0000-0003-1439-7240

https://doi.org/10.26881/gsp.2021.3.10

\section{Glosa}

Komentowany wyrok ${ }^{1}$ Wojewódzkiego Sądu Administracyjnego $w$ Łodzi jest stosunkowo rzadkim przykładem rozstrzygnięcia w kwestii, która wpisuje się w problematykę szeroko rozumianego prawa klimatycznego. Dotyczy bowiem legalności decyzji w przedmiocie opłaty za korzystanie ze środowiska za wydane uprawnienia do emisji gazów cieplarnianych za 2015 rok na rzecz spółki A. Instytucja opłat za korzystanie ze środowiska za wydane uprawnienia do emisji na zasadach określonych w ustawie z dnia 12 czerwca 2015 r. o systemie handlu uprawnieniami do emisji gazów cieplarnianych ${ }^{2}$ wpisuje się $w$ system prawnej ochrony powietrza, będącej fundamentem prawa ochrony klimatu ${ }^{3}$. Jak wskazuje Janina Ciechanowicz-McLean, opłaty za

\footnotetext{
1 Wyrok WSA w Łodzi z 29 sierpnia 2018 r., II SA/Łd 301/18, www.nsa.gov.pl, zakładka orzecznictwo [dostęp: 1.06.2021].

${ }_{2}$ Tekst jedn.: Dz. U. z 2021 r., poz. 332 ze zm.; dalej: u.s.h.u.e.

3 Por. J. Ciechanowicz-Mc Lean, Prawo ochrony klimatu, Warszawa 2016, s. 17 i s. 55.
} 
korzystanie ze środowiska stanowią „,władczo ustaloną cenę za korzystanie z zasobów środowiska [tu: powietrza - przyp. D.T.] i za wprowadzanie w nim zmian [poprzez oddziaływania - przyp. D.T.]", w sposób zgodny z prawem, określony w stosowanym pozwoleniu ${ }^{4}$. U podstaw aksjologicznych opłat za korzystanie ze środowiska leży zasada „zanieczyszczający płaci”, będącą konstytucyjną zasadą w porządku prawnym Polski (por. art. 86 Konstytucji $\mathrm{RP}^{5}$ ) i podstawową zasadą ustawy - Prawo ochrony środowiska ${ }^{6}$, oraz podstawową zasadą prawa europejskiego (por. art. 191 ust. 2 Traktatu o funkcjonowaniu Unii Europejskiej ${ }^{7}$ ). Instytucja ta zarazem ma charakter powszechny w Unii Europejskiej bowiem przywołana wyżej ustawa o systemie handlu w zakresie swojej regulacji wdraża szereg aktów prawa europejskiego, w tym w szczególności dyrektywę 2003/87/WE Parlamentu Europejskiego i Rady z dnia 13 października 2003 r., ustanawiającą system handlu przydziałami emisji gazów cieplarnianych w Unii oraz zmieniającą dyrektywę Rady 96/61/WE ; dyrektywę Parlamentu Europejskiego i Rady 2010/75/UE z dnia 24 listopada 2010 r. w sprawie emisji przemysłowych (zintegrowane zapobieganie zanieczyszczeniom i ich kontrola ${ }^{9}$ ) oraz dyrektywę Parlamentu Europejskiego i Rady (UE) 2015/2193 z dnia 25 listopada 2015 r. w sprawie ograniczenia emisji niektórych zanieczyszczeń do powietrza ze średnich obiektów energetycznego spalania $^{10}$. W kwestii charakteru prawnego analizowanych opłat, w doktrynie wskazuje się, że są one świadczeniem pieniężnym ${ }^{11}$ ponoszonym za legalne korzystanie ze środowiska przez podmioty z niego korzystające, którymi są przede wszystkim przedsiębiorcy i jednostki organizacyjne niebędące przedsiębiorcami, eksploatujące instalacje, z których użytkowaniem związane jest wprowadzanie do nich określonego rodzaju zanieczyszczeń ${ }^{12}$.

Komentowane orzeczenie zapadło w następujących okolicznościach faktycznych.

Będąca przedsiębiorcą, a zarazem podmiotem korzystającym ze środowiska spółka A. korzystała z jego zasobów w 2015 r. w sposób określony w art. 273 ust. 1 pkt 1 a

\footnotetext{
4 Ibidem, s. 57.

5 Konstytucja Rzeczypospolitej Polskiej z dnia 2 kwietnia 1997 r. (Dz. U. Nr 78, poz. 483 ze zm.).

6 Por. art. 7 ustawy z dnia 27 kwietnia 2001 r. - Prawo ochrony środowiska (tekst jedn.: Dz. U. z 2020 r., poz. 1219 ze zm.; dalej: p.o.ś.).

Traktat o funkcjonowaniu Unii Europejskiej z dnia 25 marca 1957 r. (tytuł: zmieniony przez art. G lit. A pkt 1 Traktatu o Unii Europejskiej (Dz.U.04.90.864/30) w związku z przystąpieniem Polski do Unii Europejskiej oraz zmieniony przez art. 2 pkt 1 Traktatu z Lizbony zmieniającego Traktat o Unii Europejskiej i Traktat ustanawiający Wspólnotę Europejską (Dz.U.UE.C.07.306.1) z dniem 1 grudnia 2009 r. (Dz.U.2004.90.864/2 z dnia 2004.04.30).

8 Dz. Urz. UE L 275 z 25.10.2003, s. 32, ze zm. - Dz. Urz. UE Polskie wydanie specjalne, rozdz. 15, t. 7, S. 631.

9 Dz. Urz. UE L 334 z 17.12.2010, s. 17, ze zm.

10 Dz. Urz. UE L 313 z 28.11.2015, s. 1, ze zm.

11 Zgodnie z art. 272 pkt 1 p.o.ś., stanowią one środki finansowo-prawne w ochronie środowiska. Por. też B. Draniewicz, Problem konstytucyjności opłat za korzystanie ze środowiska, PiP 2007, nr 7, s. 70-81. K. Gruszecki, Opłaty za korzystanie ze środowiska. Glosa do postanowienia NSA z dnia 21 grudnia 2004 r., OZ 828/04, GSP - Prz. Orz. 2006, nr 1, s. 17-22. W. Fill, Opłata jako prawnofinansowy instrument gospodarowania odpadami, FK 2012, nr 10, s. 36-44.

12 Por. art. 3 pkt 49 i pkt 4 p.o.ś., dotyczący definicji zanieczyszczeń i emisji.
} 
p.o.ś. Zatem powinna ponieść za ten rok kalendarzowy opłatę z tytułu przydzielonych uprawnień do emisji. Wywiązując się z tego obowiązku spółka A. uznała, że przy ustalaniu opłaty należy przyjąć ogólną liczbę uprawnień do emisji przydzielonych jej na 2015 r., niezależnie od daty ich faktycznego wydania na rachunek posiadania operatora $\mathrm{w}$ rejestrze Unii ${ }^{13}$. W konsekwencji, w przedłożonym wykazie nie uwzględniła uprawnień wydanych w 2015 r., które były przydzielone na rok 2014, a uwzględniła uprawnienia wydane w 2016 r., które były przydzielone na rok 2015.

Powyższe wyliczenie zakwestionowały organy ochrony środowiska obu instancji. W ich ocenie, spółka A. zastosowała błędną metodykę wyliczenia należnej opłaty, co skutkowało wadliwym ustaleniem jej wysokości. Rozbieżność stanowisk w tym zakresie polega na tym, że według stanowiska orzekających organów, przy ustalaniu opłaty należy wziąć pod uwagę całkowitą liczbę uprawnień do emisji wydanych na rachunek posiadania operatora w rejestrze Unii w 2015 r., niezależnie od tego, na jaki rok zostały przydzielone. W konsekwencji, w wydanej decyzji organy uwzględniły uprawnienia wydane w 2015 r., które były przydzielone na rok 2014, a nie uwzględniły uprawnień wydanych w 2016 r., które były przydzielone na rok 2015. Organy w tym zakresie odwołały się przede wszystkim do brzmienia art. 274 ust. 1a p.o.ś., z którego wynika, że opłata stanowi iloczyn „liczby uprawnień do emisji wydanych na rachunek posiadania operatora (...) w rejestrze Unii" oraz „obowiązującej stawki opłat za wprowadzanie gazów lub pyłów do powietrza w zakresie emisji dwutlenku węgla w roku, na który przydzielono uprawnienia". Dokonując wykładni cytowanego przepisu, wskazały, że jedną ze zmiennych we wzorze matematycznym, służącym obliczaniu wysokości tej opłaty, jest liczba uprawnień do emisji wydanych na rachunek posiadania operatora w rejestrze Unii (nie zaś liczba uprawnień do emisji przydzielonych instalacji na dany rok). Zatem do ustalenia wysokości opłaty za ten rok należy przyjąć całkowitą liczbę uprawnień do emisji wydanych w jego trakcie na rachunek posiadania operatora w rejestrze Unii, niezależnie od tego, na jaki rok były one przydzielone.

Kwestionując kolejne decyzje organów w odwołaniu, a następnie w skardze do sądu administracyjnego, spółka A. argumentowała, że uprawnienia do emisji gazów cieplarnianych przydzielone jej instalacjom na rok 2014, a wydane na początku 2015 r., zostały całkowicie skonsumowane do rozliczenia emisji za 2014 r. i nie było już ich na rachunkach instalacji. Co więcej, za 2014 r. strona uiściła opłatę środowiskową równoważną całkowitej ilości wyemitowanego $\mathrm{CO}_{2}$, a więc przyjęcie stanowiska organu oznaczałoby w istocie obciążenie jej podwójną opłatą za uprawnienia przydzielone na 2014 r.

Wojewódzki Sąd Administracyjny w Łodzi w wydanym wyroku uchylił zaskarżoną decyzję samorządowego kolegium odwoławczego (SKO) oraz poprzedzającą ją decyzję marszałka województwa, nie podzielając stanowiska orzekających w sprawie

\footnotetext{
13 Rejestr Unii oznacza rejestr, o którym mowa w art. 4 rozporządzenia delegowanego Komisji (UE) 2019/1122 z dnia 12 marca 2019 r. uzupełniającego dyrektywę 2003/87/WE Parlamentu Europejskiego i Rady w odniesieniu do funkcjonowania rejestru Unii (Dz. Urz. UE L 177 z 2.07.2019, s. 3 oraz Dz. Urz. UE L 177 z 2.07.2019, s. 66).
} 
organów. W ocenie sądu, istota sporu sprawdza się do kwestii związanych z dokonaniem ustaleń faktycznych dotyczących uprawnień do emisji gazów cieplarnianych, dotyczących roku 2014, a wydanych w roku 2015, a następnie subsumpcji tych ustaleń faktycznych pod właściwą normę prawną. Analiza treści przepisów obowiązującej ustawy pozwala przyjąć, że obowiązkiem opłatowym objęte są uprawnienia do emisji gazów przyznane w roku 2015 na rok 2015 i lata następne, a nie - jak przyjęły organy administracji w niniejszej sprawie - również na rok 2014. W stosunku do uprawnień przyznanych w roku 2015 na rok 2015 i lata następne można bowiem przyjąć, iż pomimo że zostały fizycznie przyznane przed wejściem w życie u.s.h.u.e., to przyjmując ustanowiony w ustawie okres rozliczeniowy oraz faktyczne korzystanie ze środowiska z tytułu przydzielonych uprawnień, jako stosunki prawne w toku, przy uwzględnieniu zasady bezpośredniego działania nowego prawa, mogą podlegać ocenie według przepisów obowiązujących w dniu dokonywania tejże oceny, tj. już po wejściu w życie tej ustawy. Taki sposób rozumienia momentu powstania obowiązku opłatowego ma bowiem swoje odzwierciedlenie w zasadzie bezpośredniego działania nowego prawa, które dopuszcza możliwość dokonywania na gruncie nowego prawa oceny skutków prawnych zdarzeń powstałych pod rządami poprzedniej ustawy (stosunki prawne w toku). Zdaniem sądu, organy administracji, uwzględniając w opłacie uprawnienia przydzielone na rok 2014, pominęły regulację art. 146 ust. 1 pkt 2 u.s.h.u.e., stanowiącą, że do opłat należnych na podstawie art. 27 ustawy o systemie handlu uprawnieniami do emisji gazów cieplarnianych ${ }^{14}$ stosuje się przepisy obowiązujące w czasie, w którym powstał obowiązek ich uiszczenia. Obowiązek uiszczenia opłaty za 2014 r., zgodnie z art. 285 p.o.ś., upłynął natomiast z dniem 31 marca 2015 r. Tym samym, zdaniem sądu, nie ma możliwości rozliczenia uprawnień na rok 2014 według u.s.h.u.e. z 2015 r., ponieważ termin rozliczenia już upłynął. Co więcej, organy administracji nie wskazały, mając na uwadze brzmienie przepisu art. 146 u.s.h.u.e., że obowiązek uiszczenia opłaty za sporne uprawnienia, powstał w późniejszym okresie. Ma to o tyle istotne znaczenie w sprawie, że Spółka podnosiła wielokrotnie na etapie postępowania administracyjnego, że uprawnienia na rok 2014 r. zostały całkowicie rozliczone.

Takie stanowisko sądu uznać należy jedynie za częściowo trafne, a w konsekwencji wymaga ono refleksji.

Podstawą prawną wydanych decyzji są przepisy przywołanej wyżej ustawy p.o.ś., ale w zakresie ich wykładni w odniesieniu do obowiązku opłatowego, uwzględnić należy również u.s.h.u.e. Ta ostatnia ustawa z dnia 12 czerwca 2015 r. weszła w życie 9 września 2015 r. $^{15}$, a więc istotny jest - na co zresztą zwrócił uwagę sąd w swoim

\footnotetext{
14 Ustawa z dnia 28 kwietnia 2011 r. o systemie handlu uprawnieniami do emisji gazów cieplarnianych (Dz. U. poz. 695 ze zm.; dalej: u.s.h.u.e. z 2011 r.).

${ }_{15} \mathrm{~W}$ uzasadnieniu do projektu tej ustawy stwierdza się, że „potrzeba uchwalenia nowej ustawy o systemie handlu uprawnieniami do emisji gazów cieplarnianych wynika przede wszystkim z konieczności zapewnienia transpozycji przepisów aktów prawa Unii Europejskiej do krajowego porządku prawnego, a w szczególności ustanowienia przepisów, które zapewnią podmiotom objętym zakresem przedmiotowej regulacji uczestnictwo w systemie na takich samych zasadach jak w przypadku podmiotów objętych systemem w pozostałych państwach członkowskich. Brak wprowadzenia powyż-
} 
uzasadnieniu - zakres jej zastosowania do rozliczenia uprawnień do emisji gazów cieplarnianych za $2015 \mathrm{r}$.

Zgodnie $z$ art. 17 u.s.h.u.e. uprawnienia do emisji przydzielane instalacjom na podstawie rozdziałów 5, 5a, 6, 10 i 11 są uprawnieniami do emisji ogólnych w rozumieniu art. 3 pkt 8 rozporządzenia Komisji (UE) nr 389/2013 ${ }^{16}$. Uprawnienia te są przydzielane instalacjom na poszczególne lata okresu rozliczeniowego na zasadach określonych w ustawie. Przy czym, wykaz instalacji i liczba uprawnień do emisji przydzielonych na dany rok dla każdej z tych instalacji są ustalane w przepisach wydanych na podstawie art. 25 ust. 4 i art. 29 ust. 1 ustawy oraz stosownie do informacji. Zasadą jest, że uprawnienia do emisji wydaje się na rachunek posiadania operatora w rejestrze Unii nie wcześniej niż od dnia 1 lutego i nie później niż do dnia 28 lutego każdego roku. Uprawnienia do emisji wydaje się w liczbie, jaka została przydzielona instalacji na dany rok. Krajowy ośrodek w terminie do 15 marca każdego roku przekazuje marszałkowi województwa informację o liczbie uprawnień do emisji: 1) wydanych w roku poprzednim na rachunek posiadania operatora, 2) zwróconych w roku poprzednim na podstawie art. 18 ust. 2 ustawy przez prowadzącego instalację.

Analizowana ustawa doprecyzowała zasady obliczania należności związanych z rozliczeniem uprawnień do emisji, przy czym jak wynika z uzasadnienia do jej projektu, podstawą obliczenia wysokości należnej opłaty jest liczba uprawnień do emisji wydanych na rachunek posiadania operatora w rejestrze Unii. Regulacja ta ma „zagwarantować podmiotom obciążonym opłatami stały mechanizm naliczania tych opłat, który związany jest z ilością wydanych, a nie przyznanych uprawnień do emisji. Różnica w podejściu do sposobu naliczania opłat jest konsekwencją korekt przydziałów uprawnień do emisji stosowanych corocznie w związku z rzeczywistymi zmianami zdolności produkcyjnej czy poziomów działalności w instalacji (zmniejszeniem

szych przepisów spowoduje, że polscy uczestnicy systemu nie będą realizowali szeregu nowych obowiązków dotyczących monitorowania emisji i sprawozdawczości w tym zakresie, Polska nie wywiąże się z obowiązków państwa członkowskiego w zakresie stosowania korekt przydziałów uprawnień do emisji, prowadzący instalacje nowe nie będą mieli możliwości skorzystania z uprawnień do emisji zgromadzonych w unijnej rezerwie, która została przewidziana jako źródło zaopatrzenia w uprawnienia do emisji dla wszystkich instalacji nowych (tj. takich, które uzyskały zezwolenia po dniu 30 czerwca 2011 r., oraz wszystkich instalacji, w których po tej dacie znacząco zwiększyła się zdolność produkcyjna, która uzasadnia dokonanie dodatkowych przydziałów uprawnień do emisji z unijnej rezerwy). Jest to okoliczność o tyle istotna, że jedną z zasad związanych z ubieganiem się o przydział uprawnień do emisji z rezerwy wprowadzonych w nowym okresie rozliczeniowym jest zasada first come, first served, co oznacza, że uprawnienia do emisji będą przydzielane według kolejności zgłoszeń, a zatem polscy przedsiębiorcy mają prawo oczekiwać, że prawodawca krajowy przyjmie regulacje, które pozwolą na skuteczne ubieganie się o przydział uprawnień do emisji z unijnej rezerwy". Por. uzasadnienie do projektu ww. ustawy (u.s.h.u.e.), projekt nr VII.3151, LEX/el.

16 Chodzi o rozporządzenie Komisji 389/2013 z dnia 2 maja 2013 r., ustanawiające rejestr Unii zgodnie z dyrektywą 2003/87/WE Parlamentu Europejskiego i Rady, decyzjami nr 280/2004/WE i nr 406/2009/ WE Parlamentu Europejskiego i Rady oraz uchylające rozporządzenia Komisji (UE) nr 920/2010 i nr 1193/2011 (Dz.U.UE.L.2013.122.1 z dnia 2013.05.03), które utraciło moc 1 stycznia 2021 r. na mocy uchylającego go rozporządzenia delegowanego Komisji nr 2019/1122 z dnia 12 marca 2019 r., uzupełniającego dyrektywę 2003/87/WE Parlamentu Europejskiego i Rady w odniesieniu do funkcjonowania rejestru Unii (Dz.U.UE.L.2019.177.3 z dnia 2019.07.02). 
zdolności produkcyjnych, częściowym zaprzestaniem działalności), które powodują zmniejszenie liczby uprawnień do emisji faktycznie wydawanych na rachunek instalacji w rejestrze. Zastosowanie tego sposobu naliczania opłat realizuje przede wszystkim interes prowadzących instalacje, którzy uregulują należności za uprawnienia do emisji, które rzeczywiście otrzymają, a nie takie, które tylko hipotetycznie otrzymałyby, gdyby prowadziły działalność na niezmienionym poziomie"17.

Odzwierciedleniem powyższego założenia jest regulacja art. 274 ust. 1a p.o.ś, w której odnaleźć można zasady obliczania opłat z tytułu korzystania ze środowiska w związku z uprawnieniami do emisji. Zgodnie z tym przepisem, wysokość opłaty za korzystanie ze środowiska w przypadku uprawnień do emisji rozdzielanych na zasadach określonych w u.s.h.u.e ustala się jako iloczyn liczby uprawnień do emisji wydanych w danym roku na rachunek posiadania operatora albo na rachunek posiadania operatora statków powietrznych w rejestrze Unii, o którym mowa w art. 8 ust. 1 tej ustawy, i obowiązującej stawki opłat za wprowadzanie gazów lub pyłów do powietrza w zakresie emisji dwutlenku węgla w roku, w którym wydano uprawnienia do emisji.

Jak prawidłowo wskazał to sąd, zgodnie z art. 281 ust. 1 p.o.ś., do ponoszenia opłat za korzystanie ze środowiska oraz administracyjnych kar pieniężnych stosuje się odpowiednio przepisy działu III ustawy z dnia 29 sierpnia 1997 r. - Ordynacja podatkowa ${ }^{18}$, z tym że uprawnienia organów podatkowych przysługują marszałkowi województwa albo wojewódzkiemu inspektorowi ochrony środowiska. Nadto, art. 284 ust. 1 p.o.ś. wskazuje, że podmiot korzystający ze środowiska ustala we własnym zakresie wysokość należnej opłaty i wnosi ją na rachunek właściwego urzędu marszałkowskiego. Podmiot ten wnosi opłatę za dany rok kalendarzowy do dnia 31 marca następnego roku (art. 284 ust. 2 p.o.ś). Natomiast, zgodnie z art. 21 § 3 o.p., jeżeli w postępowaniu podatkowym organ podatkowy stwierdzi, że podatnik mimo ciążącego na nim obowiązku nie zapłacił w całości lub w części podatku, nie złożył deklaracji, albo powstałego zobowiązania nie wykazano, organ podatkowy wydaje decyzję, w której określa wysokość zobowiązania podatkowego.

Oceniając dokonane przez organy ustalenia faktyczne odnośnie uprawnień do emisji gazów cieplarnianych dotyczących roku 2014, a wydanych w roku 2015, sąd prawidłowo odwołał się do przepisów przejściowych wynikających z u.s.u.h.e., bowiem jak wskazano powyżej, wejście w życie u.s.u.h.e. we wrześniu 2015 r. bez wątpienia mogło mieć wpływ na sposób rozliczenia uprawnień do emisji za lata 2014 i 2015. Jak się wydaje, w ramach analizy właśnie tych przepisów, sąd orzekający w niniejszej sprawie pominął konsekwencje wynikające $z$ art. 146 ust. 2 u.s.h.u.e., które mają znaczenie w kontekście przesądzenia, na ile nowe unormowania i zasady ponoszenia opłat wynikające z u.s.h.u.e. powinny znaleźć zastosowanie w niniejszej sprawie, a więc do uprawnień do emisji przydzielonych instalacjom za rok 2014, a wydanych na początku 2015 r.

\footnotetext{
17 Uzasadnienie projektu u.s.h.u.e., projekt nr VII.3151, LEX/el.

18 Ustawa z dnia 29 sierpnia 1997 r. - Ordynacja podatkowa (tekst jedn.: Dz. U. z 2020 r., poz. 1325 ze zm.; dalej: ordynacja podatkowa, o.p.).
} 
Zgodnie z treścią art. 146 ust. 1 u.s.h.u.e., do opłat należnych na podstawie: 1) art. 25 ustawy z dnia 22 grudnia 2004 r. o handlu uprawnieniami do emisji do powietrza gazów cieplarnianych i innych substancji ${ }^{19}$, 2) art. 27 u.s.h.u.e. z 2011 r.) - stosuje się przepisy obowiązujące w czasie, w którym powstał obowiązek ich uiszczenia. Jednakże, z ust. 2 tego przepisu wynika, że do opłaty, o której mowa w art. 27 u.s.h.u.e. z 2011 r., należnej za 2013 r., stosuje się przepisy tej ustawy, z tym że podstawą obliczenia wysokości należnej opłaty jest liczba uprawnień do emisji wydanych na rachunek posiadania operatora w rejestrze Unii._Zarazem, jeżeli opłata, o której mowa w ust. 2, wniesiona przez prowadzącego instalację przed dniem wejścia w życie niniejszej ustawy jest wyższa niż opłata, której podstawą obliczenia jest liczba uprawnień do emisji wydanych na rachunek posiadania operatora w rejestrze Unii, to różnica ta stanowi nadpłatę. Do nadpłaty stosuje się odpowiednio przepisy ordynacji podatkowej (ust. 3 art. 146 u.s.h.u.e.). Powyższy przepis przejściowy zatem, odczytywany w jego całokształcie, prowadzi do wniosku, że nowe zasady obliczania wysokości należnej opłaty za korzystanie ze środowiska za wydane uprawnienia do emisji znajdują zastosowanie już do opłat należnych za 2013 r. Wprawdzie w odniesieniu do tych opłat zastosowanie znajdują przepisy dotychczasowe, jednak z uwzględnieniem „nowego”, gdyż wynikającego z u.s.h.u.e., sposobu wnoszenia opłaty, tj. którego podstawą jest liczba uprawnień do emisji wydanych na rachunek posiadania operatora w rejestrze Unii. Wbrew stanowisku zawartemu w glosowanym orzeczeniu uznać należy, że tym bardziej trzeba je zastosować do opłat za 2014 r. i następne lata, a więc do okoliczności niniejszej sprawy. Tymczasem, sąd w glosowanym orzeczeniu uznał, że w odniesieniu do uprawnień spółki A. za 2014 r. nie mogą znaleźć zastosowania nowe zasady i należy je ocenić na gruncie dotychczasowych przepisów, bowiem termin rozliczenia tych opłat już upłynął, a ponadto - opłaty te zostały już całkowicie rozliczone.

W tym zakresie powyższego stanowiska sądu nie można podzielić. Cytowany art. 146 ust. 2 u.s.h.u.e. ustanawia jasne reguły zastosowania nowych zasad odnośnie do sposobu wnoszenia opłaty za korzystanie ze środowiska za wydane uprawnienia do emisji. Dotyczą one opłat za 2013 r. i kolejne okresy. Wprowadzenie nowych zasad może wiązać się z powstaniem nadpłaty na kontach konkretnych operatorów, co do rozliczenia których zastosowanie znajduje instytucja nadpłaty w oparciu o przepisy ordynacji podatkowej. Słusznie zatem SKO wskazywało na taką prawną możliwość, bowiem zastosowanie tej instytucji bez wątpienia wyklucza zasadność „podwójnego” obciążania podmiotu korzystającego ze środowiska omawianą opłatą. W konsekwencji, uznać należy, że w okolicznościach niniejszej sprawy prawidłowe były ustalenia i wykładnia cytowanych przepisów dokonana przez organy administracji. W sprawie opłaty za korzystanie ze środowiska związanej z wydaniem uprawnień do emisji gazów cieplarnianych za 2015 r. spółce A. zastosowanie winna znaleźć reguła wyrażona w przywołanym art. 273 ust. 1 pkt 1a p.o.ś. w zw. z art. 274 ust. 1a p.o.ś, z której wynika, że opłatę tę ustala się jako iloczyn „liczby uprawnień do emisji wydanych na rachunek posiadania operatora w rejestrze Unii” oraz „obowiązującej stawki opłat za

19 Dz. U. Nr 281, poz. 2784. 
wprowadzanie gazów lub pyłów do powietrza w zakresie emisji dwutlenku węgla w roku, na który przydzielono uprawnienia". Sporną zmienną zatem jest liczba uprawnień do emisji wydanych na rachunek posiadania operatora w rejestrze Unii w danym roku, nie zaś liczba uprawnień do emisji przydzielonych instalacji na dany rok. W konsekwencji, uznać należy, że prawidłowe w okolicznościach niniejszej sprawy było stanowisko organów, zgodnie z którym do ustalenia wysokości opłaty za 2015 r. należało przyjąć całkowitą liczbę uprawnień do emisji wydanych w jego trakcie na rachunek posiadania operatora w rejestrze Unii, niezależnie od tego, na jaki rok były one przydzielone. Okoliczność, na jaki rok przydzielono uprawnienia do emisji, ma jedynie znaczenie w odniesieniu do drugiej zmiennej, czyli stawki opłaty.

Powyższą wykładnię potwierdza również treść uzasadnienia do projektu u.s.h.u.e., w którym napisano, że "do opłat za wprowadzanie do powietrza gazów cieplarnianych objętych systemem uiszczonych przed dniem wejścia w życie niniejszej ustawy stosuje się przepisy dotychczasowe, z tym że podstawą obliczenia wysokości należnej opłaty jest liczba uprawnień do emisji wydanych na rachunek posiadania operatora w rejestrze Unii. Przepis ten ma znaczenie porządkowe i gwarantuje podmiotom obciążonym opłatami stały mechanizm naliczania tych opłat, który związany jest z ilością wydanych, a nie przyznanych uprawnień do emisji. Różnica w podejściu do sposobu naliczania opłat jest konsekwencją korekt przydziałów uprawnień do emisji stosowanych corocznie w związku z rzeczywistymi zmianami zdolności produkcyjnej czy poziomów działalności w instalacji (zmniejszeniem zdolności produkcyjnych, częściowym zaprzestaniem działalności), które powodują zmniejszenie liczby uprawnień do emisji faktycznie wydawanych na rachunek instalacji w rejestrze. Zastosowanie tego sposobu naliczania opłat realizuje przede wszystkim interes prowadzących instalacje, którzy uregulują należności za uprawnienia do emisji, które rzeczywiście otrzymają, a nie takie, które tylko hipotetycznie otrzymałyby, gdyby prowadziły działalność na niezmienionym poziomie. Projekt ustawy przewiduje także mechanizm wyrównywania opłat wniesionych przed wejściem w życie ustawy w wyższej wysokości niż wymagana, wskutek proponowanej zmiany sposobu naliczania opłat za wprowadzanie gazów i pyłów do powietrza. Powstała w ten sposób nadpłata będzie mogła zostać rozliczona na zasadach określonych w Ordynacji podatkowej" ${ }^{20}$. Wprowadzone zasady zatem wyraźnie rozróżniają kwestię przydziału uprawnień od ich wydania na rachunek posiadania operatora, przy czym ich rozliczenie opłatą za korzystanie ze środowiska powiązane zostało jednoznacznie z liczbą uprawnień do emisji „,wydanych w danym roku na rachunek posiadania operatora". Takie reguły, wprowadzone w celu ujednolicenia reguł rozliczania uprawnień do emisji w całej Unii Europejskiej, powinny znaleźć zastosowanie także w okolicznościach niniejszej sprawy.

Reasumując, kierunek przyjęty w glosowanym orzeczeniu uznaję zasadniczo za prawidłowy. Sąd bowiem prawidłowo zinterpretował wprowadzenie nowych zasad uiszczania opłat za korzystanie ze środowiska za wydane uprawnienia do emisji, określone w u.s.h.u.e., wiążąc je ze sporną w okolicznościach niniejszej sprawy liczbą uprawnień

$\overline{20}$ Por. uzasadnienie projektu u.s.h.u.e., projekt nr VII.3151, LEX/el. 
do emisji „,wydanych w danym roku na rachunek posiadania operatora” (niezależnie od tego, na jaki rok były one przydzielone). Ostatecznie jednak, odmiennie niż uznał to sąd, biorąc pod uwagę treść przywołanych wyżej przepisów przejściowych, zasady wynikające z tej ustawy, dotyczące podstawy obliczenia wysokości należnej opłaty mają zastosowanie także do opłat za 2014 i 2015 r., co powinno znaleźć odzwierciedlenie w odmiennym rozstrzygnięciu sądowym niż to, które zapadło w sprawie. W tym aspekcie zatem komentowane orzeczenie budzi moje zastrzeżenia. W konsekwencji, glosę powyższą należy zakwalifikować jako częściowo krytyczną.

\section{Literatura}

Ciechanowicz-McLean J., Prawo ochrony klimatu, Warszawa 2016.

Draniewicz B., Problem konstytucyjności opłat za korzystanie ze środowiska, PiP 2007, nr 7.

Gruszecki K., Opłaty za korzystanie ze środowiska. Glosa do postanowienia NSA z dnia 21 grudnia 2004 r., OZ 828/04, GSP - Prz. Orz. 2006, nr 1.

Fill W., Opłata jako prawnofinansowy instrument gospodarowania odpadami, FK 2012, nr 10.

\section{Streszczenie}

\section{Diana Trzcińska}

Problematyka obliczania opłat za korzystanie ze środowiska za wydanie uprawnień do emisji gazów cieplarnianych

Autorka poddaje analizie wyrok Wojewódzkiego Sądu Administracyjnego w Łodzi, na mocy którego uchylone zostały decyzje organów obu instancji, ustalające wysokość opłaty z tytułu korzystania ze środowiska za wydane uprawnienia do emisji gazów cieplarnianych za 2015 r. na rzecz podmiotu korzystającego ze środowiska. Ostatecznie częściowo podziela przyjętą przez sąd analizę przepisów prawa, wyrażając zastrzeżenia co do wykładni mających zastosowanie w sprawie przepisów przejściowych ustawy z dnia 12 czerwca 2015 r. o systemie handlu uprawnieniami do emisji gazów cieplarnianych.

Słowa kluczowe: prawo ochrony klimatu; opłata za korzystanie ze środowiska; system handlu uprawnieniami do emisji gazów cieplarnianych. 


\section{Summary}

\section{Diana Trzcińska}

\section{Calculation of the Fee for the Use of the Environment for the Granted Greenhouse Gas} Emission Allowances

The Author examines the judgment of the Voivodship Administrative Court in Łódź in which the court repealed the decisions of the administrative authorities of both instances determining the fee for the use of the environment for the greenhouse gas emission allowances granted in 2015 according to the principles set out in the Act of 12 June 2015 on the greenhouse gas emission allowance trading system. The Author partly accepts the court's positions with some reservations concerning the application of transitional provisions.

Keywords: climate law; fee for the use of the environment; greenhouse gas emission trading system. 